\title{
11. Material. Human. Divine. Notes on the Vertical Screen
}

\author{
Noam M. Elcott
}

\begin{abstract}
Taking cues from architecture, painting, and experimental cinema, Noam Elcott maps three distinct paradigms for the format of the vertical screen. Portraiture - the erect human figure or face - may be understood as the eponymous and paradigmatic form of this vertical format. Vertical screens also align with the celluloid strips that run vertically through nearly all projectors, whose properties were interrogated by postwar avant-gardes and have taken on renewed urgency in light of celluloid's impending obsolescence. Finally, the luminous verticality of stained glass windows helped define the Gothic order, which provided a model for avant-garde experiments in light and space for a century or more, and which have suddenly returned to centre stage in contemporary art. Elcott's three distinct paradigms map a centuries-long encounter with vertical screens that resonate unexpectedly yet unambiguously in the present.
\end{abstract}

Keywords: Format, Media Archaeology, Contemporary Art, Installation, Phantasmagoria

\section{Past prisms present}

Screens For Looking at Abstraction (2011-), a multi-part installation by Josiah McElheny, encapsulates the whole history of abstract cinema. Selections from the canon and margins of abstract film-projected upside-down, backwards, and in reverse - are refracted horizontally, vertically, or prismatically across a series of mirrors and screens to form new kaleidoscopic configurations. (Figure 11.1) These visual symphonies immediately conjure the iridescent images produced on Sir David Brewster's kaleidoscope

Buckley, C., R. Campe, F. Casetti (eds.), Screen Genealogies. From Optical Device to Environmental Medium. Amsterdam: Amsterdam University Press, 2019 DOI 10.5117/978946372900o_CH11 
(patented in 1817), A. Wallace Rimington's Colour Organ (patented in 1895), Alexander B. Hector's Apparatus for Creating Colour Music (patented in 1921), the lumia of Thomas Wilfred (to which I will return), and hosts of other commercial, scientific, and artistic ventures. One quickly recalls the abstract films of Walter Ruttmann and Hans Richter (in the 1920s), Len Lye (beginning in the 1930s), and Stan Brakhage (in the later part of his career), as well as the Whitney brothers' pioneering use of analogue computers (beginning in the late 1950s) and Douglas Trumbull's adaption of the slit-scan technique for the Star Gate sequence in 2001: A Space Odyssey (Stanley Kubrick, 1968). The multiplied, folded, and expanded screens point, in turn, to the proliferation of screens in the Farblichtmusik performances of Oskar Fischinger and Alexander Laszlo (in the 1920s), the Expanded Cinema of Stan VanDerBeek, Robert Whitman, and others from the 196os and 1970s as well as myriad recent film and video installations. More than any single reference, however, Screens For Looking at Abstraction encapsulates the history of abstract film because the installation's parts are literally devices for viewing the history of abstract film. McElheny lets others program the films. But the operations he mandates - films must be projected upsidedown, backwards, and in reverse; and then refracted further by angled mirrors - render virtually any footage abstract. Accordingly, the whole history of film is mobilized for the experience of abstraction. Generations earlier, the inveterate Dadaist Man Ray bricolaged a functionally identical apparatus for his personal use: 'I go to the movies without choosing the program, without even looking at the posters. I go to the theatres that have the comfortable seats. [...] I invented a prism system that I adapted on to my glasses: this way, I watch black and white films that bore me in colours and in abstract images.' ${ }^{1}$ For Man Ray and McElheny, abstraction inheres not only in the works but also and above all in their exhibition. For Man Ray and his circle, the operative element was lenses. For McElheny and our generation, the operative element is screens.

It is time we looked at cinema not through a different lens but on a different screen: the vertical screen. More than any other force in recent years, the vertical screen has changed our orientation to cinema, whether mass-produced or avant-garde, industrial or artistic, contemporary or historical. A single technological device - the smartphone-has made vertical screens ubiquitous. But their origins and reverberations run much deeper and have only begun to be charted. This is a brief and schematic overview of vertical screens. 


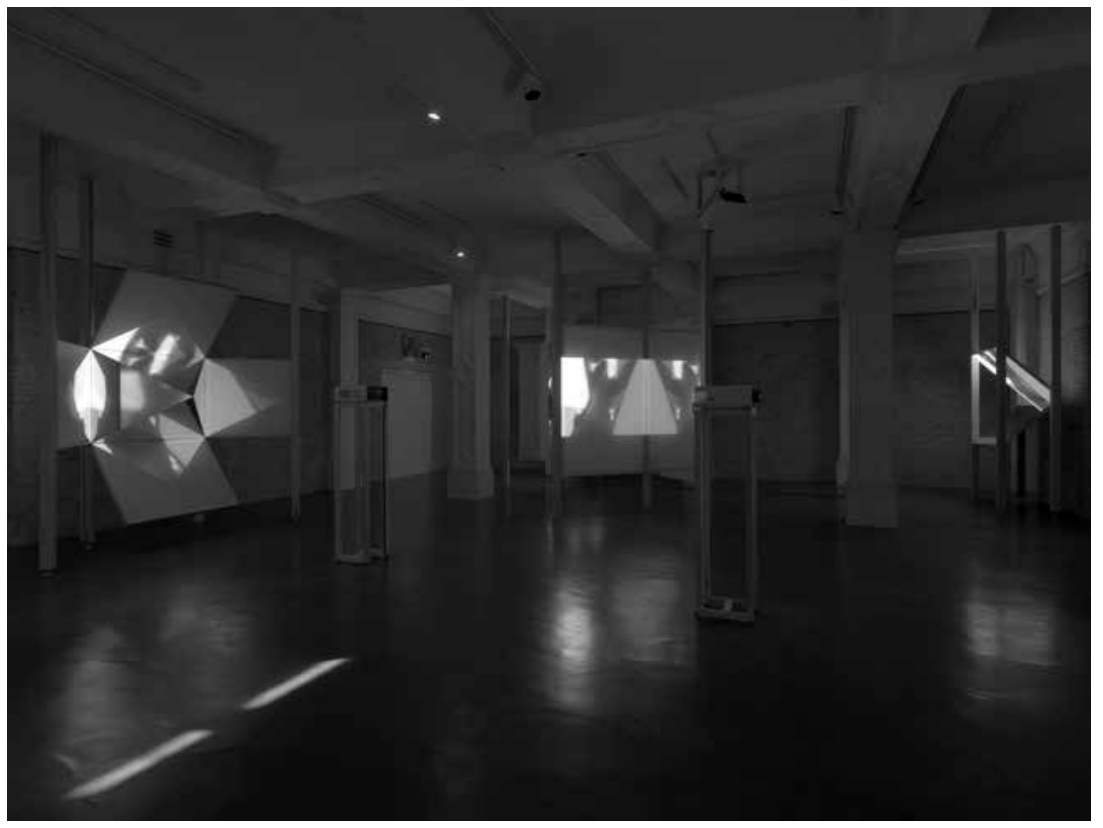

11.1: Josiah McElheny (b.1966), Screens for Looking at Abstraction, 2012. Aluminum, low-iron mirror, projection cloth, film transferred to video (variable program), video projectors with stands, wood, metal hardware; three parts, overall dimensions variable. (c) Josiah McElheny.

\section{Tall screens, buried histories}

A century ago, new screens were still reliant on new lenses. In late 1926, the French astronomer and inventor Henri Chrétien applied for a patent for an anamorphic lens, called the Hypergonar, in the hopes of advancing early efforts in colour and stereoscopic (or $3 \mathrm{D}$ ) cinema. ${ }^{2}$ These efforts appear to have gone nowhere. But as is so often the case in the history of technology, an invention patented for one application proved to be the solution for an altogether different problem. The catalyst was Abel Gance's 1927 cinematic epic Napoléon. For the dramatic conclusion of the film, Gance employed a triple-projector system known as Polyvision in which three traditional cameras and projectors were interlocked to produce vast panoramas and highly choreographed triptychs across a 4:1, super-widescreen field. Inspired by Gance, Chrétien repurposed his Hypergonar anamorphic lens toward a new cinematic experience: not widescreen but rather a cinematic cross 
that could accommodate 1.33:1 at its centre (for conventional scenes), 2.66:1 widescreen (for panoramas), and 1:2.66 'tall-screen' suitable, according to Chrétien's patent application, for the interiors and façades of churches, among other scenes. (Figure 11.2) Understood as an added attraction rather than as a standard format, a number of directors, not least Claude AutantLara, mobilized the Hypergonar anamorphic lens to produce films with widescreen and 'tall-screen' sequences, a feat accomplished using two projectors outfitted with anamorphic lenses mounted horizontally and vertically. ${ }^{3}$ In the late 1920s, 'tall-screen' cinema was technologically no less viable than widescreen cinema. Yet given the choice between tall-screen cinema and widescreen cinema, professionals and publics resoundingly chose sound cinema. Chrétien's Hypergonar anamorphic lens was quickly abandoned and forgotten until its $195^{2}$ re-discovery and rebranding as Cinemascope.

Twice buried in the history of Cinemascope lies a history of the vertical screen. It is a history previously consigned to failed technological experiments and other antiquarian anecdotes. Today, however, it is the history of the present. Spurred by the vertical video captured and played on smartphones, YouTube, Facebook, and other leading video portals have recently enabled full-screen vertical video. For billions of users, vertical video is now a normative format. ${ }^{4}$ And yet, vertical cinema is at once new and ancient. Whether on canvas or on the iPhone, vertical orientation is known as portrait format. The cinematic incunabula of Muybridge and Marey were often oriented vertically, as were the slits or mirrors of phenakistoscopes, zoetropes, praxinoscopes, and other nineteenth-century 'pre-cinematic' optical toys-not least because they took their measure from the erect human. And there is no question that the social practice of portraiture-codified as an aesthetic genre centuries or millennia ago — gets us closer to vertical cinema than does the iPhone. As Gilles Deleuze famously remarked: 'Technology is [...] social before it is technical. 5 But the social practice of portraiture does not get us close enough. For the screen-whatever its orientation-has no essence, no apodictic form, no timeless ideal. Instead - and here is the wager that undergirds the speculations to come-if screens have no essence, they nonetheless manifest clear propensities, such that certain types of screens promote and

3 Decades later, Disney retrofit Fantasia with a variable aspect ratio projection system to stretch the animated sequences to 2:1 widescreen, while the live-action sequences retained their 1.33 format. See Wasserman, pp. 14-15.

4 See Manjoo, 2015.

5 Deleuze, pp. 39-40. 


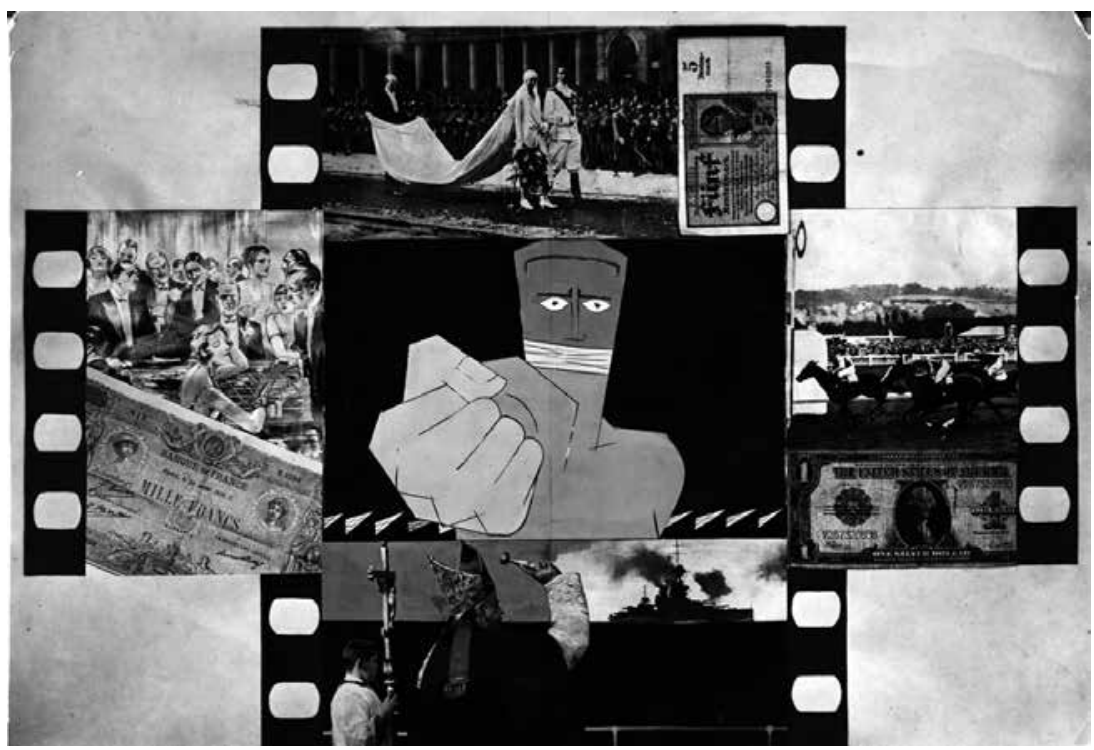

11.2: Claude Autant-Lara (1901-2000), Collaged mockup for Construire un Feu (1928-30). Courtesy John Belton.

inhibit certain types of images in specific types of locations. Screens have no essence, but neither is their deployment merely a product of chance. ${ }^{6}$

What follows is a series of speculations on the broader, longer cultural associations and technical implementations of the vertical screen. I will draw on recent and comparatively archaic instances of vertical cinema in an effort to map three distinct paradigms for the vertical screen. Portraiture - that is, the erect human figure or face - is surely the eponymous and paradigmatic form of the vertical format. I will return to the question of portraiture in the middle of this essay, albeit mediated through the ghostly scrim of the phantasmagoria. I will also examine two additional paradigms. On the one hand, vertical screens align with the celluloid strips that run vertically through nearly all projectors. For the last fifty years, verticality hinted at film's otherwise invisible material support, whose properties were interrogated by postwar avant-gardes and have taken on renewed urgency in

6 For nuanced reflections on the arbitrary and the more fundamental non-mimetic elements of images — such as frames, rectangularity, left/right and up/down — see Meyer Schapiro's 'On Some Problems in the Semiotics of Visual Art'. Alas, Schapiro's comments on orientation are limited to the commonplace that 'We live more in the horizontal dimension than the vertical' and, ultimately, that 'I shall pass over the role of proportions and shape of the field, which is a vast problem'. Schapiro, 1972, pp. 13 and 15 . 
light of celluloid's impending obsolescence. On the other hand, the luminous verticality of stained glass windows helped define the Gothic order, provided a model for avant-garde experiments in light and space for a century or more, and have suddenly returned to centre stage in art world debates. In short: I will explore vertical screens and vertical cinema in relation to three distinct paradigms: material, human, and divine. Although hardly exhaustive, these three topoi will map a centuries-long encounter with vertical screens that resonates unexpectedly but unambiguously in the present.

\section{Eisenstein's dynamic square}

In the late 1920s, widescreen and 'tall-screen' cinema were technologically feasible, practically implemented, and vigorously debated. With the advent of sound film, the 1.33:1 aspect ratio that lorded over cinema since the days of Edison and the Lumières came under pressure. Sound-on-film - that is, an optical soundtrack printed alongside the image — colonized precious celluloid real estate and reduced the already squat 1.33 ratio to a mere 1.18, an all-but-square format. (Fritz Lang's $M$ [1931] is perhaps the most famous film released in this aspect ratio.) At the same time, directors and technicians frequently championed but rarely realized ever wider formats. Many of these aesthetic and technical reflections were recounted in a special issue of The Journal of the Society of Motion Picture Engineers, a Hollywoodbased association, published in January 1930. Representatives from the scientific bureau of Bausch \& Lomb Optical Co. or Bell and Howell Camera Co. affirmed widescreen for reasons 'artistic, technical, and economic' as well as 'psychological, metaphysical, and physiological'? The affirmation of horizontality was nothing less than axiomatic. ${ }^{8}$ And yet it was in this milieu-specifically, at a September 1930 meeting organized by the Technicians Branch of the Academy of Motion Picture Arts and Sciences in Hollywood - that the great Soviet director and contrarian Sergei Eisenstein staged his intervention into the proper proportions of the film screen.

The talk was soon published in the important English-language film journal Close-Up. Rather than champion widescreen cinema and accept as

7 Howell and Dubray, pp. 82, 6o, and passim.

8 Just a few years ago, an ultimately futile campaign against vertical video spawned countless YouTube videos, many of which capture the axiomatic adherence to cinematic horizontality as well as the earlier scientific papers — and with much more hilarity. See, for example, 'Vertical Video Syndrome' at https://youtu.be/BtgzSfinwFA. 
axiomatic the horizontality of the screen, Eisenstein marshalled the brewing debate to question the basic assumptions that had governed cinematic proportions for more than three decades. Physiologically, economically, and, above all, aesthetically, the horizontal screen, according to Eisenstein, was little more than a residue of the theatrical origins of cinema. Film images were horizontal because stages - and paintings modelled after stages - were horizontal. Eisenstein, to the contrary, embraced 'the hymn of the male, the strong, the virile, active vertical composition!' ${ }^{\prime}$ Lest he offend the sensitive listener, Eisenstein did not elaborate at length on 'the dark phallic and sexual ancestry of the vertical shape as a symbol of growth, strength or power'. Rather, and in concert with Freud's Civilization and its Discontents, published the same year, he rehearsed humanity's evolution from worms, creeping on their stomachs, to four-legged animals, only to become 'something like mankind from the moment when we hoisted ourselves to our hind legs and assumed the vertical position'. Man then 'marked in vertical milestones each step in his progress to a higher level of social, cultural or intellectual development': Indian lingams, Egyptian obelisks, Trajan's column, the Christian cross, the Gothic arch, the Eiffel Tower, and, in his own time, the ultimate sublimated phalluses, armies of skyscrapers, rows of chimneys, and trellises of oil-pumps. But here, at the height of his vertical psalm, Eisenstein's argument took a surprising turn:

By now, surely, you will have deduced that my suggestion for the optical frame of the supreme and most synthetic of all arts [the cinema] [...] is that it must be vertical.

Not at all.

For in the heart of the super-industrialised American, or the busily self-industrialising Russian, there still remains a nostalgia for infinite horizons, fields, plains and deserts. [...] This nostalgia cries out for horizontal space. [...]

So neither the horizontal nor the vertical proportions of the screen alone is ideal for it.

$[\cdots]$

What is it that, by readjustment, can in equal degree be made the figure for both the vertical and horizontal tendencies of a picture? The battlefield for such a struggle is easily found - it is the square [...] The 'dynamic' square screen..$^{10}$ 
Parenthetically but potently, Eisenstein specifically rejected the vertical proportions attained by masking the right and left sections of the frame - as seen, for example throughout Lotte Reiniger's animated silhouette fairytale Cinderella (1922) or The Holy Mountain (1926), a mountain film by Arnold Fanck, starring Leni Riefenstahl. For Eisenstein, 'The vertical spirit can never be attained this way: first, because the occupied space comparative to the horizontal masked space will never be interpreted as something axially opposed to it, but always as part of the latter and, second, because in never surpassing the height that is bound to the horizontal dominant, it will never impress as an opposite space axis - the one of uprightness.'11 Thus, Eisenstein abandoned the vertical screen, teeming with the dark phallic and sexual ancestry of the vertical shape, in favour of the more dialectical and dynamic square screen — which he failed to act on all the same. Indeed, neither Eisenstein nor his Hollywood technician audience nor any other major forces in cinema succeeded in promulgating a screen much different from the 1.33:1 ratio established by Thomas Edison's deputy, W.K.L. Dickson, in 1892. A year after Eisenstein's speech was published, the Academy of Motion Picture Arts and Sciences adopted the so-called Academy ratio of 1.375:1. The dynamic square, the erect phallus, and the nostalgia for infinite horizontal fields would remain, for decades, unrequited dreams.

\section{Materiality}

Nearly 85 years after Chrétien proposed $35 \mathrm{~mm}$ anamorphic vertical cinema, Tacita Dean inadvertently landed on precisely the same procedure. A maker of beautiful, haunting, and above all melancholic works in film and other media, Dean received the final Unilever commission for the Tate Modern's cavernous Turbine Hall - a long, narrow, and exceptionally tall exhibition space. The shape of the project, quite literally, appeared to her instantly:

I wanted to try and make a portrait format anamorphic film with the lens I normally use to stretch my film into a double-width landscape format. I wondered what would happen if I turned the lens 90 degrees and stretched the image from top to bottom instead of from left and right: make a portrait format film for a portrait format space ${ }^{12}$ 
From the beginning, then, Dean aligned the vertical format with portraiture and a portrait format space. But a central question remained unanswered: a film portrait of what? 'I realized', she said, 'I was making an ideogram and, unbeknown to me, the portrait l'd been struggling to recognise for so long was a portrait of film itself'. ${ }^{13}$ Dean jettisoned nearly all post-production and all digital effects in favour of antiquated modes of in-camera editing using glass matte painting, multiple exposures, and masks - in particular, the iconic sprocket holes visible on the left and right of every vertical frame - to create an iridescent film that captured the unique qualities of film. She then projected the looped film vertically onto a 13-meter high monolith. Thus, the history of the 2011 work aptly titled: FILM. (Figure 11.3)

Dean's vertical cinema piece is silently shot through with a materialistand feminist - history of film, above all works of structural and materialist filmmakers in the U.S. and Europe, such as Film in Which There Appear Edge Lettering, Sprocket Holes, Dirt Particles, Etc. (1966), by George Landow (now known as Owen Land), or Malcolm Le Grice's Little Dog for Roger (1967), a $16 \mathrm{~mm}$ film whose primary content is an old home movie shot on $9.5 \mathrm{~mm}$, a film gauge famous for its central sprocket hole and which, by the late 1960s, was rapidly approaching obsolescence. In other words, these were precisely the preoccupations of Dean. ${ }^{14}$

Annabel Nicolson-Le Grice's student and Dean's future mentor-advanced this aesthetic with a distinctly feminist edge in a number of formative works from the early 1970s. In her film Slides (1971), for example, Nicolson ran the celluloid through a sewing machine, wove it with thread, collaged shreds of photographic transparencies and filmstrips directly on the celluloid, and pulled it by hand through a Debrie step printer. And in her classic Expanded Cinema piece, Reel Time (1973), she ran film through a sewing machine and a projector, puncturing and eventually destroying the film. Although these films maintain traditional aspect ratios, the verticality of the filmstrip produces the unambiguously dominant axis. This verticality is precisely not aligned with the male, the virile, and the phallic, as Eisenstein suggested, but with women's work — editing as sewing — as announced already in Vertov's epoch-making film, Man with a Movie Camera (1929), whose eponymous cameraman (Mikhail Kaufman, Vertov's brother) must

13 Ibid., p. 28.

14 The material substrate of film is frequently confused with its essence or ontology. As P. Adams Sitney and Malcolm Le Grice recognized decades ago in their essay 'Narrative Illusion vs. Structural Realism', this argument often boils down to warmed over Greenbergianism misapplied to cinema. Le Grice and Sitney, p. 145. On the historically variable-rather than ontologically stable — roles played by celluloid in avant-garde art and film, see Elcott, 2008. 


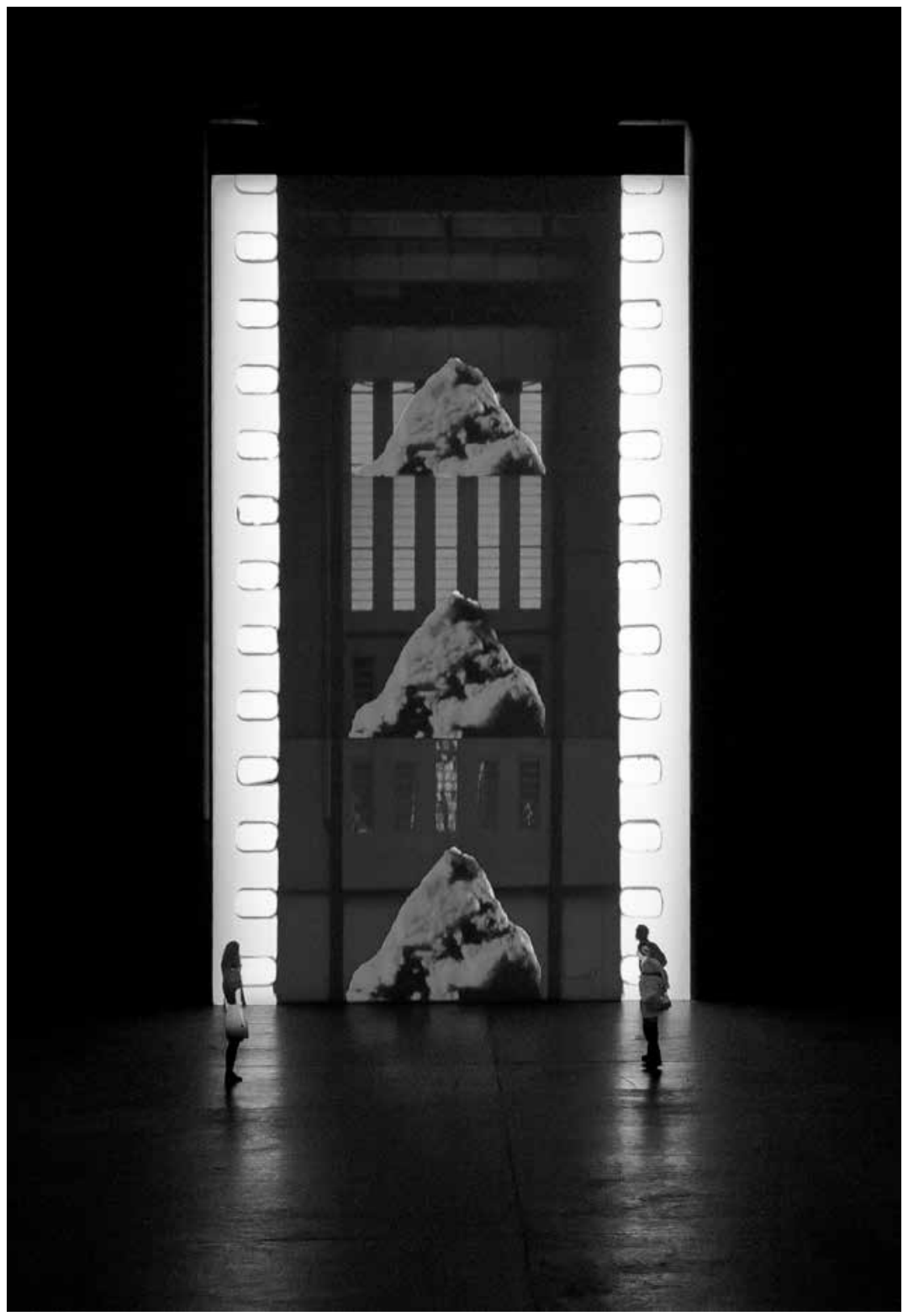

11.3: Tacita Dean (b.1965), FILM, 2011. 35mm color and black and white portrait format anamorphic film with hand-tinted sequences, silent, 11 minutes, continuous loop.

Installation view: The Unilever Series: Tacita Dean, FILM. 11 October 2011 - 11 March 2012, Turbine Hall, Tate Modern. Photo $\odot$ Tate. Courtesy: The Artist and Marian Goodman Gallery New York/Paris; Frith Street Gallery, London. 
yield to the film's editor (Elizaveta Svilova, Vertov's wife) whenever the material celluloid enters the picture. As contemporary artist and theorist Hito Steyerl has argued: 'In the age of reproduction, Vertov's famous man with the movie camera has been replaced by a woman at an editing table, baby on her lap, a twenty-four-hour shift ahead of her."15

In the context of vertical cinema proper, however, an even more immediate analogue comes to mind: the films and installations or 'locational' films of Paul Sharits. In S:TREAM:S:S:ECTION:S:ECTION:S:S:ECTIONED (1970), Sharits superimposed multiple shots of streaming water and then slowly overlaid these camera images with scratches that run the length of the celluloid, thereby foregrounding the materiality of the filmstrip and that of the screen. As Rosalind Krauss argued at the time: 'For film, the world of experience-all photographic experience-is trapped between these two parallel flatnesses', the screen and the filmstrip. The dramatization of this fact is the basis for Sharits's film. ${ }^{6}$ We might augment Krauss's account with the equally vital recognition that the world of experience-all cinematic experience-is also caught between the horizontality of the screen and the verticality of the strip, which becomes the basis of the film's development as the live-action stream of water slowly gives way to vertical scratches that course down the celluloid or, as Sharits explained, 'A conceptual lap dissolve from "water currents" to "film strip current". The underlying tension between vertical filmstrips and horizontal aspect ratio is brought to a boil in his 1982 locational film titled $3^{\text {rd }}$ Degree. The installation includes three projectors rigged with mirrors so that they throw vertical images. The content of the images is of a filmstrip being run through an optical printer, sprocket holes and all. These filmstrips, in turn, depict the face of a woman, who appears to be threatened with a match. The filmed filmstrips advance haltingly, sometimes stopping before the lamp so long that the celluloid boils and burns, thus the titles of the installation- $3^{\text {rd }}$ Degree - and of the single-screen version, Bad Burns. The film of the burning filmstrips is subsequently run through the optical printer, creating two and then three generations of filmstrips whose recursive logic is matched only by their material precariousness and violence. In $3^{\text {rd }}$ Degree, the vertical image and physical filmstrip would be aligned unambiguously except that Sharits has flipped the images on their sides through mirrored projection so that the depicted filmstrips and their plainly visible sprocket holes now advance horizontally. Instead of a one-to-one correspondence between image and 


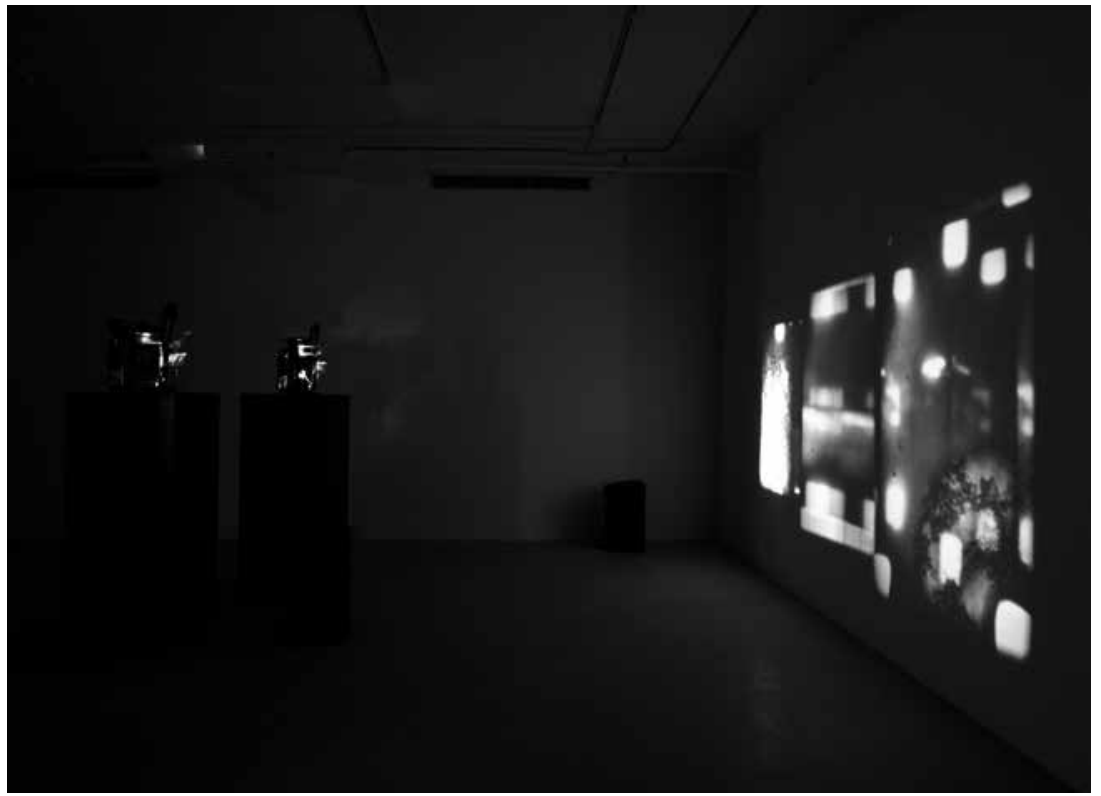

11.4: Paul Sharits (1943-1993), 3rd Degree, 1982. $16 \mathrm{~mm}$, color, sound, 24fps. Duration: looped films 7 1/2 min each. Courtesy the Paul Sharits Estate and Greene Naftali, New York.

material support, Sharits choreographs a recursivity of doubt that envelops the original footage, the three generations of film, their vertical projection, and, ultimately, the viewer's place therein. (Figure 11.4)

This tension between vertical filmstrips and horizontal aspect ratio is even more pronounced in Sharits's Frozen Film Frames series (from the 1970s), in which he suspended strips of celluloid between sheets of Plexiglas such that the strips maintain their vertical flow but often take on proportions like 55 in. by 41.61 in., that is, precisely 1.33:1. (Figure 11.5) The Frozen Film Frames were an elaboration of Peter Kubelka's earlier installation of Arnulf Rainer (1960), where the celluloid strips were mounted horizontally on the wall. Jennifer West has recently added her own version to this historical series in 'film quilts' like Magic Lantern Film Quilt Underwater Anamorphic Moon (2015), comprised of 35mm and $70 \mathrm{~mm}$ filmstrips, and measuring $5^{2}$ in. by 40 in. or 1.3:1. Unlike Sharits or Kubelka, however, West's celluloid strips undergo alchemical transformations induced by nail polish, ink, Axe body spray, lavender mist air freshener, skateboard tire marks, Ho-Hos, melon juice, lipstick, and numerous other material interventions by West and her often anonymous collaborators (such as London skateboarders). Such physical 


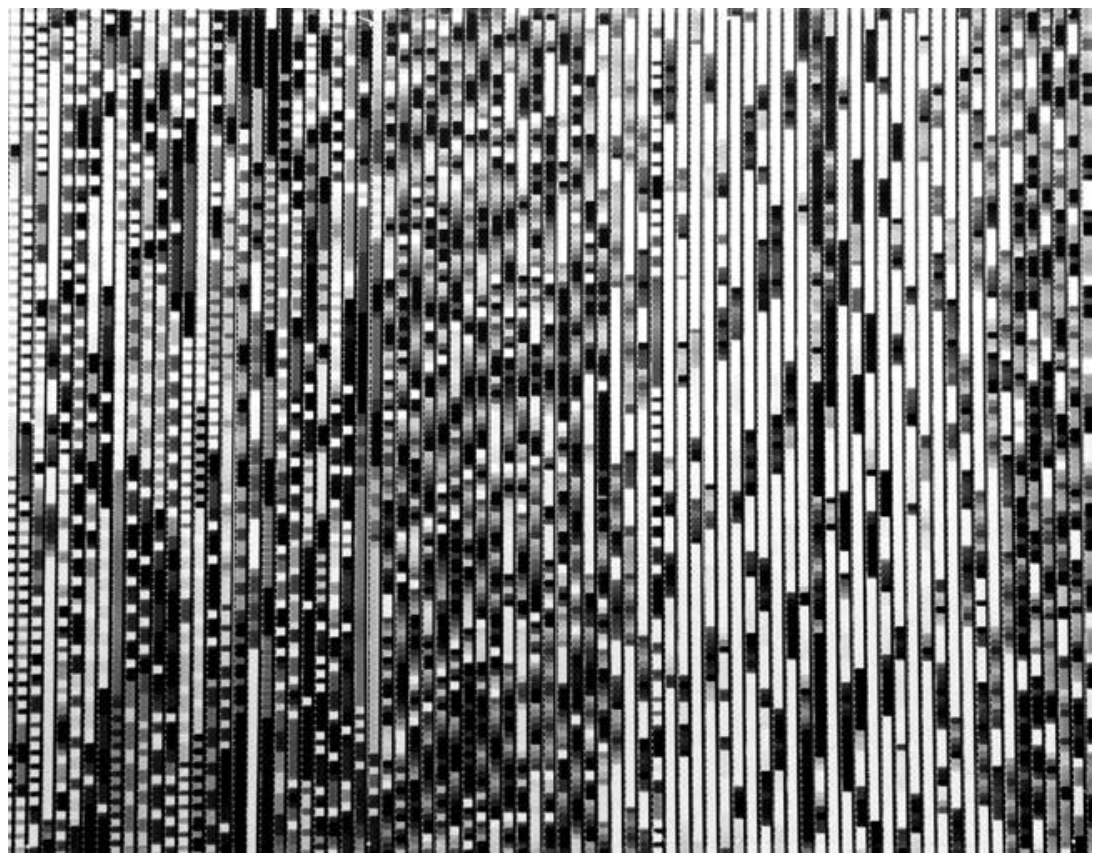

11.5: Paul Sharits (1943-1993), Untitled (Frozen Film Frame), c.1971-76. 16mm film strips and Plexiglas, $411 / 2 \times 55 \times 1 / 4$ inches overall $105.4 \times 139.7 \times .6 \mathrm{~cm}$. Courtesy the Paul Sharits Estate and Greene Naftali, New York.

transmogrifications most famously recall the camera-less films of Stan Brakhage. More importantly, they evoke the pickled, stir-fried, deep-fried, and other cooking-based films by Tony Conrad, which, as Branden Joseph has demonstrated, were part and parcel of a broader reckoning between materialist and feminist practices, that is, between filmmaking and homemaking. ${ }^{17}$ Where Conrad's cooking confronts 'timeless' gender norms, West's nail polish, Axe body spray, and lipstick encounter their perennial construction.

\section{Human/ghost}

From the eighteenth-century spectacular attraction perfected by ÉtienneGaspard Robertson through Gary Hill's 1992 Documenta video installation Tall Ships, phantasmagorias have effected an assembly of bodies and images 
in real time and space. ${ }^{18}$ In Robertson's phantasmagoria, spectators were immersed in darkness and ghoulish figures were projected onto translucent screens or clouds of smoke such that they appeared to occupy the same space as the spectators. (Figure 10.6) In Hill's Tall Ships, spectators were immersed in darkness and forlorn figures were projected onto invisible black walls such that they appeared to occupy the same space as the spectators. In these and other phantasmagorias, images are not distant visions (like those proffered in the cinema), nor are they circumscribed pictures (like those enclosed in frames or television sets); instead, they appear to abandon their material supports and enter our world. Stripped of the derisive connotations prevalent already in nineteenth-century discourse and concentrated to toxic intensity by Adorno and others in the twentieth century, phantasmagoria—or, more precisely, the phantasmagoric dispositif - simply and directly describes the (perceived) assembly of bodies and images in real time and space. The phenomenon is a mainstay of live and recorded audio. ${ }^{19}$ And it is sweeping the world under the erroneous rubric of holography. Tupac Shakur, Michael Jackson, Chief Keef, and the French communist politician Jean-Luc Mélénchon, who used the technique to campaign simultaneously in two places at once, are just a handful of the figures recently resurrected or teleported 'holographically', that is, by means of the nineteenth-century technology called Pepper's Ghost (and originally designated 'the Dircksian Phantasmagoria'). Similarly, the innumerable devices hawking 'augmented reality'—such as Microsoft's HoloLens and Google Glass - speak to the contemporary obsession with a world suffused with living images. Even as the histories of art and film are littered with phantasmagoria-from Bernini's Ecstasy of Saint Teresa (1647-1652) through Ken Jacobs's decades-long pursuit of $3 \mathrm{D}$ cinema-the upsurge in recent decades is pronounced. Robert Whitman's Shower (1964), Gary Hill's Tall Ships (1992), Diller-Scofidio's 1998 ballet EJM, Fiona Tan's Correction (2004), Rodney Graham's Torqued Chandelier Release (2005), Bill Viola's Ocean Without a Shore (2007), Richard Maxwell's Ads (2010), and Carrie Mae Weems's Lincoln, Lonnie, and Me (2012) are just several of the countless major and minor works best understood neither as paintings or sculptures nor as cinematic films or theatrical dramas but rather as phantasmagorias. Each work engenders the sensation that the image

18 For a more extensive discussion of phantasmagoria, treated separately from the question of verticality, see Elcott, 2016.

19 See Sterne, pp. 110-131. The greatest artistic practitioners of phantasmagoric sound today are surely Janet Cardiff and George Bures Miller. See Uroskie, pp. 1-3. 


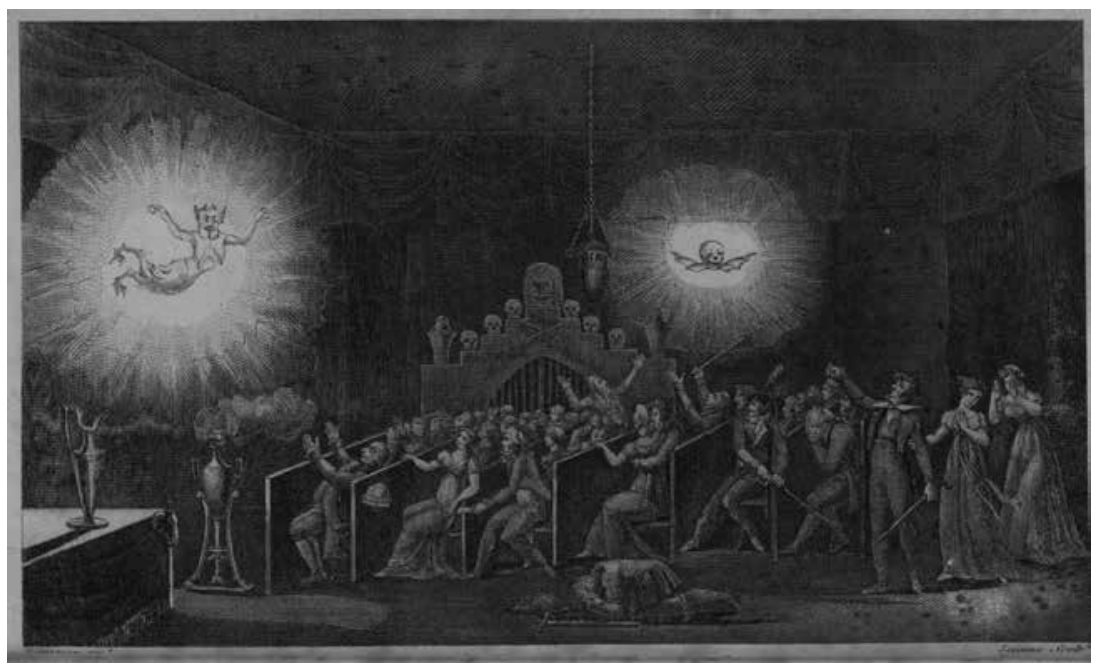

11.6: Étienne-Gaspard Robertson (1763-1837). Frontispiece from Mémoires récréatifs, scientifiques et anecdotiques. (1831-1833).

may be real or, at the very least, that 'the images have been freed into the materiality of real time and space. ${ }^{20}$ Among the few elements shared by these utterly disparate works is the vertical screen.

Exemplary-in its technical implementation, if not its aesthetic and philosophical pretensions-is Viola's Ocean Without a Shore: a highdefinition video triptych installed in the Church of San Gallo as part of the 2007 Venice Biennale. Three enormous plasma screens mounted vertically and three pairs of stereo speakers were inserted into the church's three altars. From the dark depths of the screen-or is it a deep recession in space?-grainy black and white figures approach a nearly imperceptible threshold that, upon contact, reveals itself as a wall of water that visually rhymes with the plasma screen. In slow motion, the actors cross the water/ plasma threshold, emerge in high-definition colour, and enter not the Land of $\mathrm{Oz}$ but the Church of San Gallo, that is, the very space we occupy, only to return to the grainy darkness from which they issued. (Figure 11.7) Ocean Without a Shore rehearses the history of video installation-from the grainy black-and-white figures who approached the viewer and retreated into the darkness of Hill's Tall Ships through the recent turn to high production values - only to arrive back at phantasmagoria as it was practiced in the eighteenth century. Robertson famously installed his phantasmagoria in a 


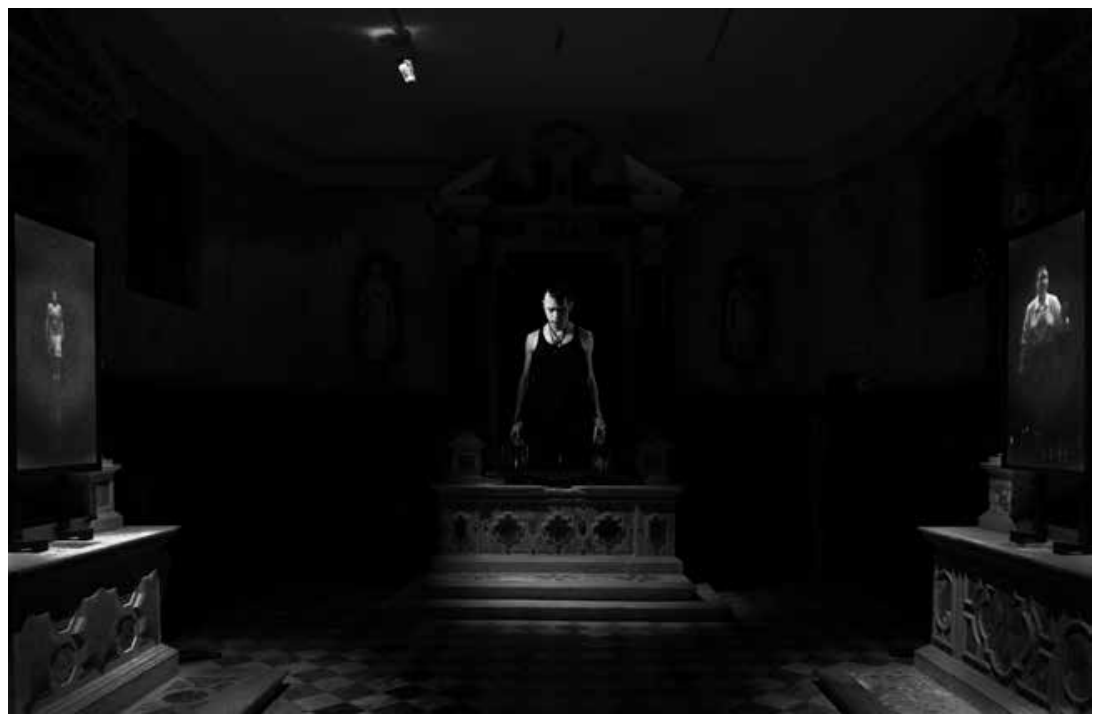

11.7: Bill Viola (b.1951), Ocean Without a Shore, 2007. High-definition color video triptych, two 65 -in. flat panel screens, one 103-in. screen mounted vertically; six loudspeakers (three pairs, stereo sound). Room dimensions: $14 \mathrm{ft} 9$ in. $\times 21 \mathrm{ft} 4$ in. $\times 34 \mathrm{ft} 5$ in. $(4.5 \times 6.5 \times$ $10.5 \mathrm{~m})$. Continuously running Performers: Luis Accinelli, Helena Ballent, Melina Bielefelt, Eugenia Care, Carlos Cervantes, Liisa Cohen, Addie Daddio, Jay Donahue, Howard Ferguson, Weba Garretson, Tamara Gorski, Darrow Igus, Page Leong, Richard Neil, Oguri, Larry Omaha, Kira Perov, Jean Rhodes, Chuck Roseberry, Lenny Steinburg, Julia Vera, Bill Viola, Blake Viola, Ellis Williams. Photo: Thierry Bal. @ Bill Viola.

Capuchin convent where he projected moving vertical figures in colour, like the Bloody Nun or the recently departed, onto invisible screens suspended in the darkness. Like the original phantasmagoria and Tall Ships, Ocean Without a Shore is a meditation on life and death: the title derives from the Andalusian Sufi mystic Ibn Arabi, who wrote that 'the Self is an ocean without a shore'.

But phantasmagoria need not get mired in ponderous metaphysics and extravagant pyrotechnics. Indeed, phantasmagoric configurations also undergird some of the most critically attuned film and video installations of the last fifty years, such as the work of Anthony McCall. Beginning with his now-canonical Line Describing a Cone (1973), McCall's solid light films comprise the projection of two-dimensional geometric forms through a misty and darkened space such that the beam of light is perceptible as a three-dimensional, immaterial sculpture. As McCall himself declared in a searing 1974 statement, the solid light films negated core aspects of the cinematic apparatus (virtual time and space, spectatorial immobility, and the frontal screen) in favour of real time, real space, and ambulatory and 
omnidirectional spectatorship. ${ }^{21} \mathrm{He}$ and others understood the work in largely negative terms. But in the longer history of cinema, the solid light films were and remain unambiguously phantasmagoric: projections on smoke in darkened spaces that assemble humans and images. As Gunnar Schmidt argues, McCall's Line Describing a Cone is 'a new combination of modern abstraction and premodern theatricality'. ${ }^{22}$ The perfect circle formed at the climax of Line Describing a Cone is oriented neither vertically nor horizontally. But other major pieces from the period-Long Film for Four Projectors (1974) or Long Film for Ambient Light (1975) — forcefully prioritize vertical blades of light or vertical screens. Given the proclivity of the phantasmagoric for the vertical, it is no surprise that McCall's recent work has introduced vertical projection down from the ceiling. Titles like Breath (2004) and Coupling (2009) allude to abstract, surrogate bodies that rise ten metres high, occupy our space, and in turn are occupied by our bodies. (Figure 11.8)

The verticality of these works exceeds the imperatives of portraiture. And yet verticality cannot be divorced from its generic past. The opposition between the horizontal landscape and the vertical portrait dates back at least to the Renaissance and likely to the late Medieval distinction between icon and narrative (or imago and historia). In so much as cinema has been a vehicle for narrative, it has remained horizontal. The vertical video formats suddenly available to billions of amateurs only solidifies-by mass consensus - the seemingly eternal link between verticality and portraiture. We might hazard that the turn to verticality stems from or even effects a shift from narrative to image, from then and there to here and now; in short, from diegesis to mimesis, telling to showing. Whereas the horizontal format frames a stage, the vertical format makes certain claims to immediate presence, ghostly absence, or, most accurately, ghostly presence.

\section{Divine}

McCall's vertical pieces have induced heavenly resonances for lay and professional audiences alike. (The fact that Between You and I [2006] has been exhibited in several decommissioned churches has only encouraged the associations-despite McCall's repeated disavowals.) Chrétien's patent application singled out the interiors and façades of churches. And 


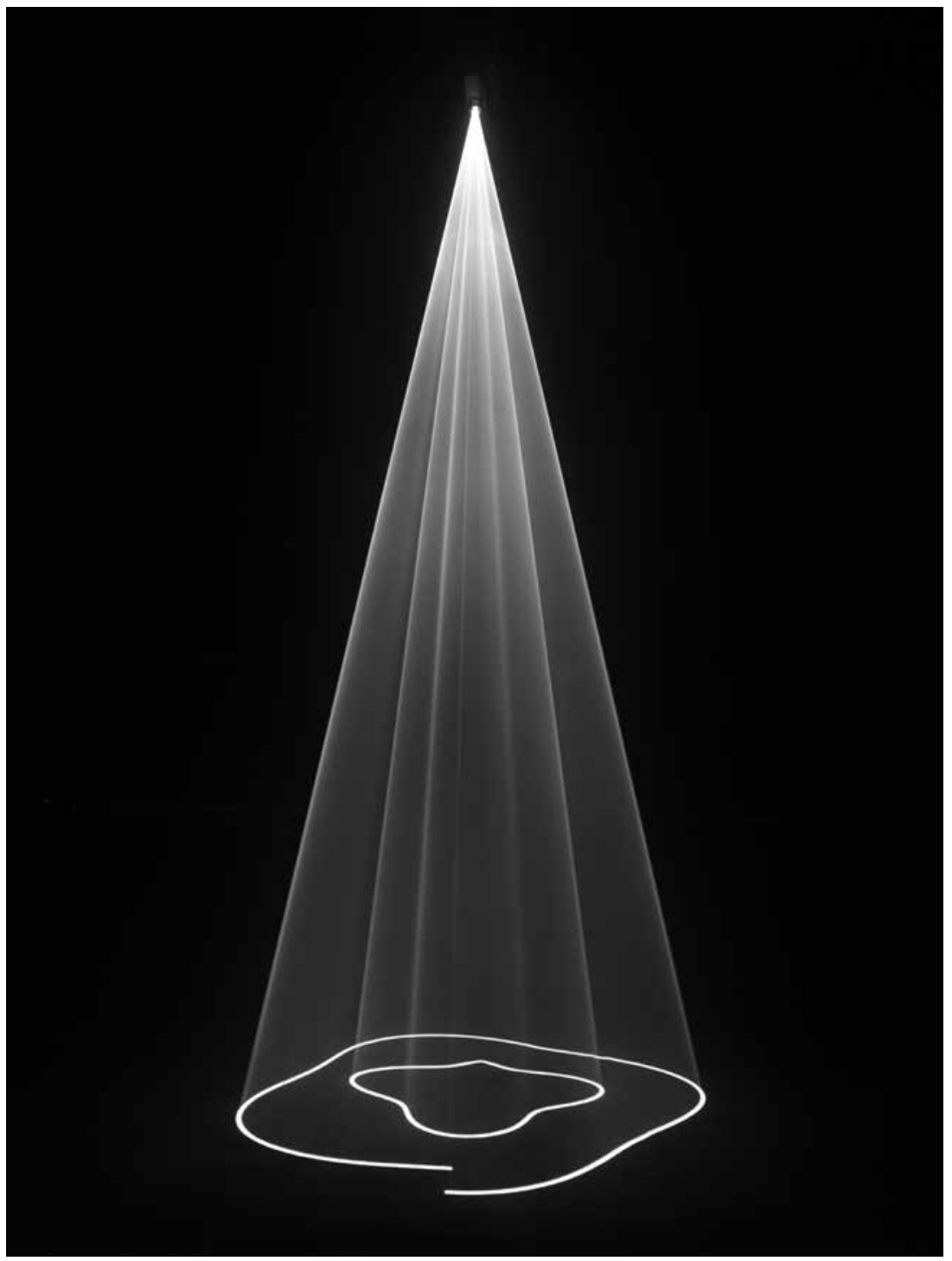

11.8: Anthony McCall (b.1946), Coupling, 2009. Video projector, computer, QuickTime Movie file, haze machine, 16 minutes. Courtesy: The artist and Sean Kelly, New York.

when Sonic Acts commissioned films for a custom 1:2.35 Cinemascope screen as part of their Vertical Cinema project (2013), they first projected them in the Klangraum Krems Minoriten Church. There is no escaping it. Vertical luminous images conjure the divine and, more precisely, evoke the earliest instance of abstract, luminous vertical screens: stained glass 
windows. ${ }^{23}$ Like countless other avant-gardists, László Moholy-Nagy espoused a 'new culture of light' and embraced screens of every size and shape. In his epoch-making treatise Painting, Photography, Film (1925/27), Moholy-Nagy traced his experiments in the direct manipulation of light back through the abstract films of Walter Ruttmann, Viking Eggeling, and Hans Richter; the colour organ performances of Thomas Wilfred and Alexander Scriabin; early efforts by Newton and his student Pater Castel; and finally, as the ur-scene of so much Bauhaus thought and practice, the lustrous Medieval cathedral and its stained glass windows. ${ }^{24}$ Herbert Molderings has rightly described Moholy-Nagy's aesthetic as a 'secularized light cosmogony'. ${ }^{25}$

Stained glass is an essential reference point because it is the oldest and most consistent instance of vertically oriented luminous screens, a tradition that runs more or less continuously from Suger's Saint-Denis cathedral in the twelfth century to De Stijl impresario Theo van Doesburg's stained glass windows, like Composition IV (1917), and Gerhard Richter's monumental stained glass window for the south transept of the Cologne Cathedral (2007), which makes explicit the link between backlit pixelated computer screens and panes of stained glass. But the link between vertical stained glass and vertical media screens had been made definitively already in Chartres Bleu (1983-1986), the most famous work by West Coast Conceptualist artist Paul Kos. Kos's radiant installation reconstructs a 27-pane stained glass window in the choir ambulatory of the Chartres Cathedral using 27 television monitors turned on their sides, that is, oriented vertically. (Figure 11.9) The choice of window was dictated not by the Biblical narrative or the beauty of the design but by the proportions of each pane of glass: 3:4 or 1:1.33, the aspect ratio of standard definition video turned on its side. ${ }^{26}$ Each monitor plays a 12-minute video loop that reconstructs - via $35 \mathrm{~mm}$ transparencies-a 24-hour cycle. The 'anagogical manner' promulgated by Suger, Abbot of Saint Denis - that is, the ascent from the material to the immaterial world ${ }^{27}$-is here braided and looped: darkness cedes to light and Gospel is birthed from the void, only for the luminosity to reach an intensity so fierce that it

23 The proportions or aspect ratios of paintings have proven irresistible catnip to big data analysts. Thus far, the conclusions tend to confirm commonplace knowledge. See, for example, Trott's 'Aspect Ratios in Art' (2015) and Roeder's 'A Nerd's Guide to the 2,229 Paintings at MoMA' (2015).

24 Moholy-Nagy, pp. 18-19.

25 Molderings, p. 14.

26 Kos and Phillips, p. 145 .

27 Suger, pp. 63-65. 


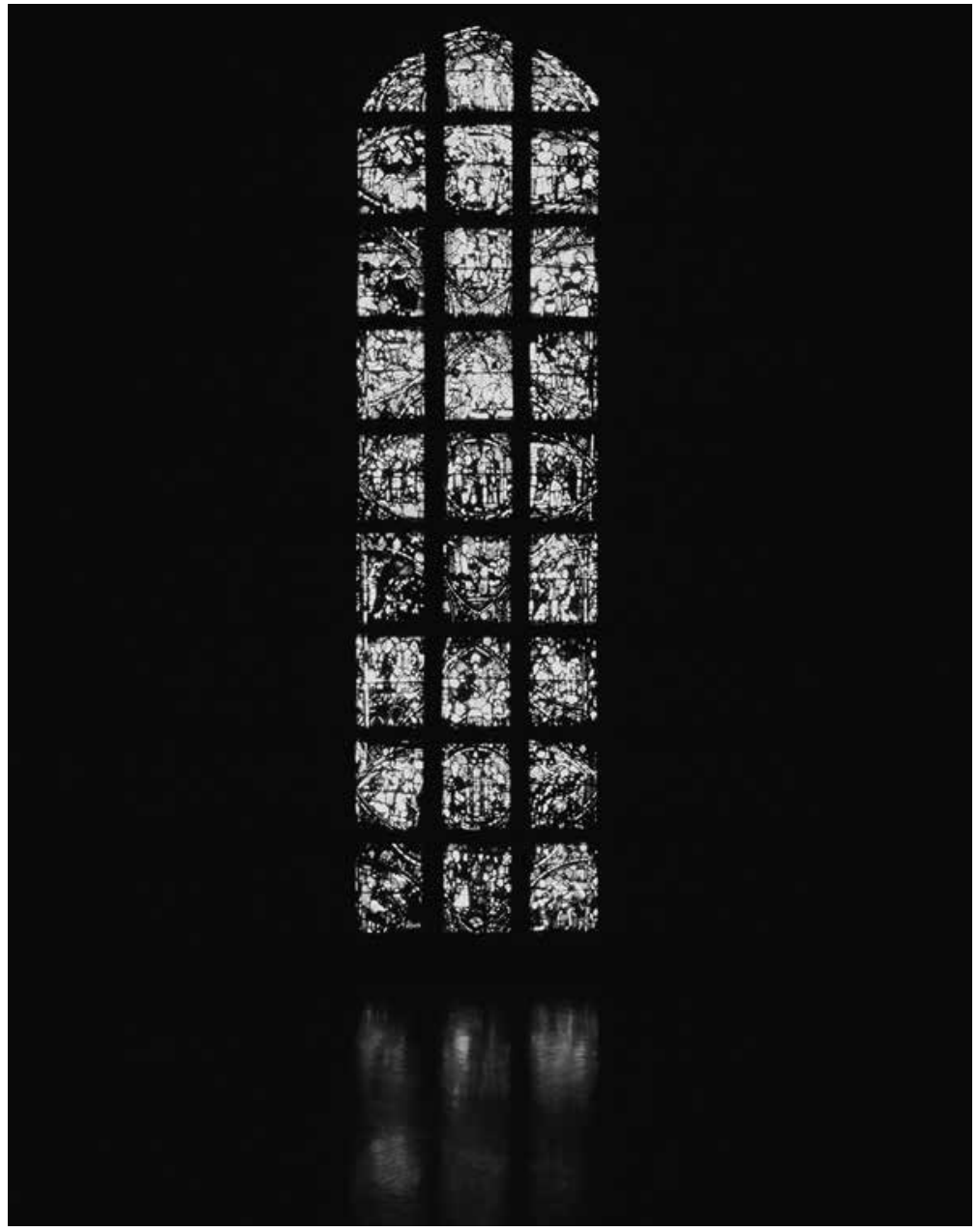

11.9: Paul Kos (b.1942), Chartres Bleu, 27 channel video installation. Edition 1 of 3. Permanently installed at di Rosa Art Preserve, Napa California. Photo: Courtesy of Paul Kos, Anglim/Gilbert Gallery, San Francisco and Galerie George -Philippe and Nathalie Valois, Paris.

obliterates the image and yields a pile of blue screens at once transcendent and opaque. The loop returns to darkness and begins the cycle anew.

For the interwar and post-WWII avant-gardes, the single most important practitioner of the art of light may very well have been Thomas Wilfred. ${ }^{28}$ The Danish-born, Parisian-trained American artist founded 'lumia', the art of light, in the early decades of the twentieth century and constructed its 
primary instrument, a colour organ dubbed the Clavilux ('light keyboard'), in 1919. (Figure 11.10) Moholy-Nagy referenced the work as early as 1922, and Wilfred has continued to inspire (but also disappoint) avant-garde and mainstream artists and filmmakers like Ken Jacobs, James Turrell, and Terrence Malick through the present. Wilfred's lumia enjoyed widespread success in the 1920 s and 1930s. He toured with conductor Leopold Stokowski and the Philadelphia Orchestra in a series of concerts in 1926, presaging Stokowski's more famous turn in Disney's Fantasia (1940). Wilfred fell into partial obscurity in the 1940s and 1950s (though he was exhibited alongside Jackson Pollock and Mark Rothko at MoMA's Fifteen Americans show [1952]). And he saw a brief revival in the 196os, including the Lumia Suite, Opus 158 (1963-1964), a major MoMA commission that resulted in what was perhaps the first looped light or film display on long-term exhibition in a major art museum.

Wilfred's lumia pieces can be likened rhapsodically to undulating curtains of light or diaphanous clouds of colour. For better or for worse, their closest mainstream analogue today are screensavers. Like most practitioners of visual music (a term Wilfred resisted), Wilfred was stirred by higher powers, be it theosophic knowledge of the divine or the sidereal firmament. He envisioned 'a major fine art' whose origins and foundation are to be found in the starry skies, 'apart from earthly phenomena and the human body'. ${ }^{29}$ The theosophic and celestial rhetoric resounded in titles like Ascending Forms or Fourth Study in Rising Forms (both 1954), but his relation to verticality was ultimately more practical, as is evidenced in a series of works straightforwardly titled Vertical Sequence I-III (1935-1941). Most relevant for a history of vertical screens, Wilfred, like Eisenstein, recognized the limitations of the traditional and expanded horizontal formats. He contrasted lumia to Cinerama and Cinemascope: 'Both of these employ "panoramic" screens [...] and both yield impressive illusions of depth. Such screen proportions, however, would not serve in lumia because so many of the lumia compositions depend on the vertical dimension for effectiveness. ${ }^{\prime 0}$ Wilfred emphatically addressed these technical limitations as soon as he shifted his emphasis from concert performances to home and gallery installations. In his first Home Clavilux models, known as the Clavilux Junior (1930), the duo-stacked walnut cabinets stored a 100-watt moving lamp, hand-painted glass disks, and other equipment on the bottom

29 Wilfred, 1969, pp. 252-253.

30 See Wilfred's unpublished manuscript Lumia, The Art of Light (1945-1947), excerpted in Stein, 67 . 


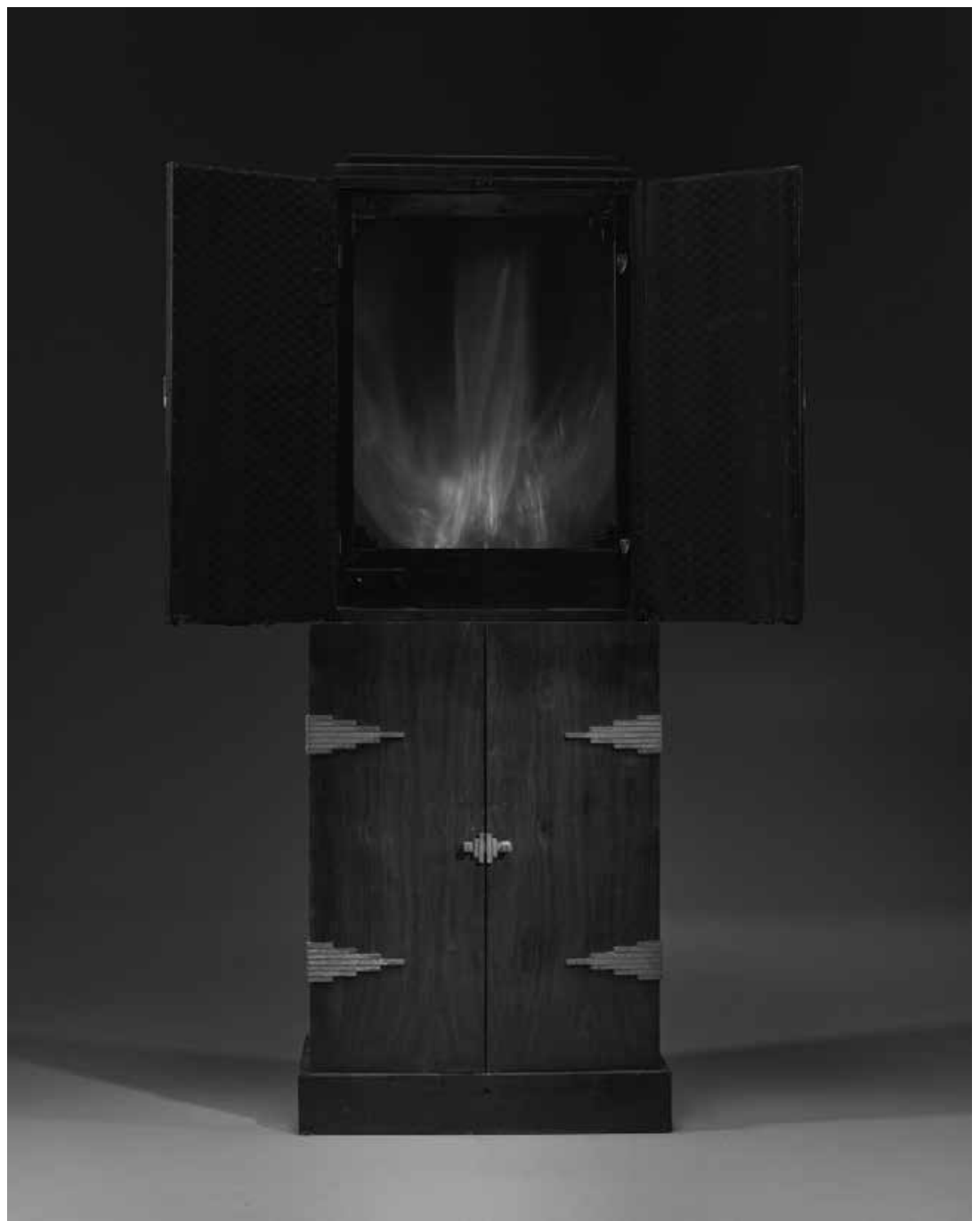

11.10: Thomas Wilfred (1889-1968), Clavilux Junior, 1930. Carol and Eugene Epstein Collection.

and a vertical screen on top. A substantial number of opuses similarly utilized vertical screens, including Counterpoint in Space (Opus 146) (1956), Multidimensional (1957), Sequence in Space (1965), and Untitled (Opus 161) (1966). (Figure 11.11) The first of these included stained-glass pieces rather than gel-based paint on the revolving colour record inside the machine, thus establishing a direct techno-material connection to vertical church windows. The last was made for a vertical screen 32 in. by 51 in., but it gained its widest audience as part of Terrence Malick's Tree of Life (2011) - a major 
motion picture otherwise suffused with 'organic' special effects created by Douglas Trumbull and others using fluorescent dyes, paints, $\mathrm{CO}_{2}$, milk, flares, and a Phantom camera shooting at 1,00o fps, which function almost independent of the pompous narrative and voiceovers. Here, to commence the creation of the universe, Wilfred's vertical cloud of colour stands in for nothing less than divine light.

Wilfred was not, however, an evangelist for vertical screens. Like Eisenstein before him, he gravitated toward a dynamic square or squat rectangle that enabled horizontal and vertical forms. MoMA's Lumia Suite, for example, is rear-projected onto an $8 \mathrm{ft}$. by $6 \mathrm{ft}$. screen, that is, in traditional 4:3 or 1.33:1. But the piece comprises three 12-minute cycles or movements: horizontal, vertical, and elliptical. Similarly, Wilfred produced the first Home Lumia Instruments (1935-1936) in horizontal and vertical models (with sides measuring 16 and 20 inches in either direction).

And so we return to McElheny's seven Screens For Looking at Abstraction to find a pervasive but also contradictory embrace of the vertical. (Figure 11.1) The artist and his interlocutors categorically understand the work as 'sculptural screens' or simply as 'sculptures'.$^{31}$ (A better analogy may be to painted altarpieces with open wings.) As sculptures, they are resoundingly vertical. With the exception of Screens For Looking at Abstraction Nos. 3 and 6, the proportions of the seven screens range from a near square 1:1.08 (No. 4 and No. 7) to a towering 1:1.83 (No. 5) — physical ratios that are markedly elongated phenomenologically through the real (rather than perceived) depth of the angled screens. ${ }^{32}$ But these sculptures are not only sculptures. They are also 'machines', in McElheny's evocative analogy to a video arcade, machines that are 'some kind of portal or entry to someplace else'. ${ }^{33}$ This 'someplace else' is often resolutely horizontal. Nowhere is the tension between sculptural verticality and virtual horizontality more pronounced than in Screen No. 1. An 84 in. by 96 in. screen flanked by two mirrors (facing each other and perpendicular to the screen), Screen No. 1 creates an infinitely regressive horizontal image whose aspect ratio is 1: $\infty$. The physical sculpture is vertical; the virtual image is boundlessly horizontal.

At the core of McElheny's Screens For Looking at Abstraction is neither the materiality of the screen nor the virtuality of the image but their mutual

31 McEhleny, Herrmann, and Trodd, p. 75 .

32 These measures do not take into account the pressure mounted vertical armature, whose dimensions vary with the space but always raise the screens off the ground and soar far above their width.

33 McEhleny, Herrmann, and Trodd, p. 8o. Early video arcade games, not least Pac-Man (1980), are another instance of pervasive vertical screens. 


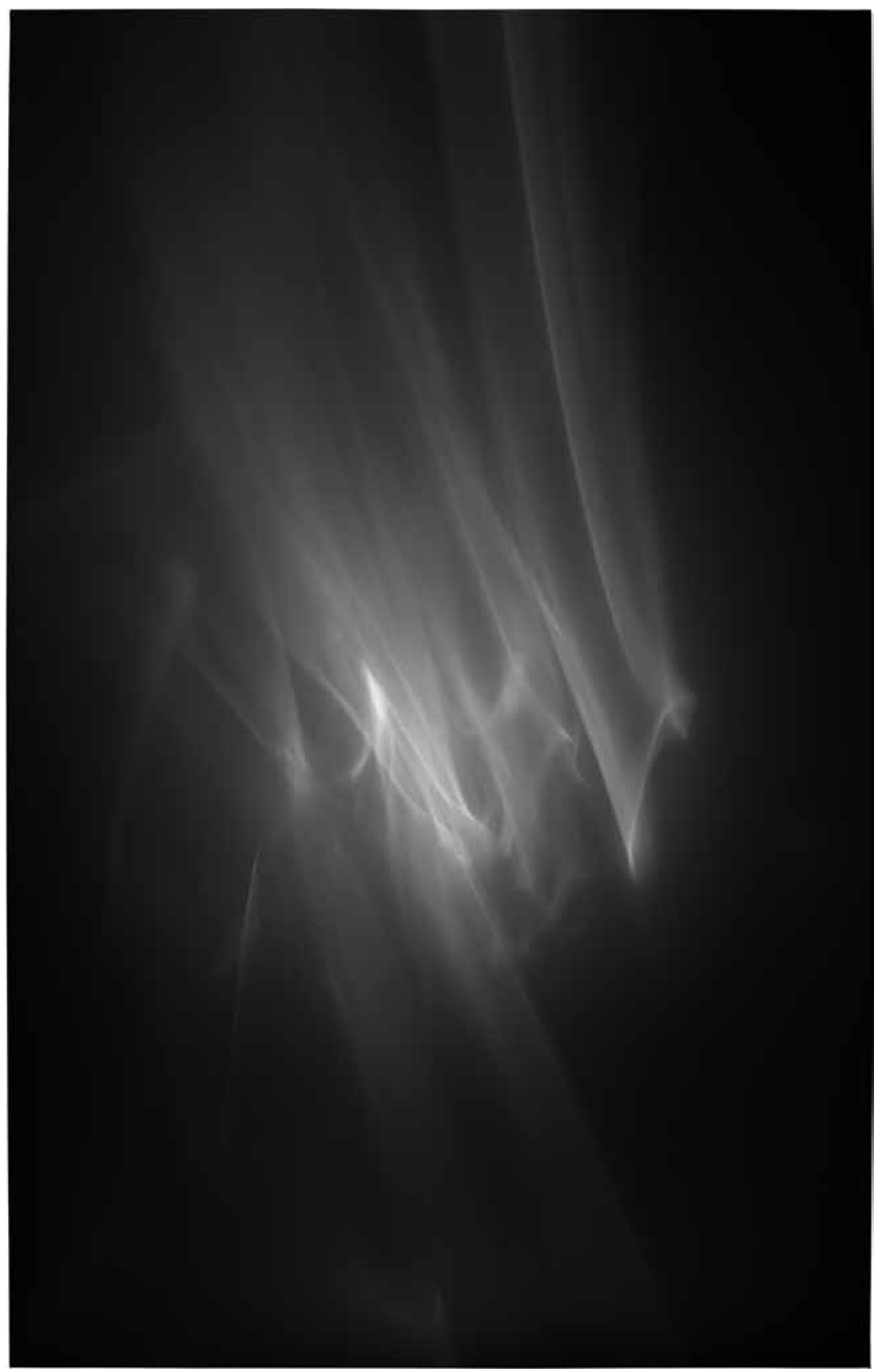

11.11: Thomas Wilfred (1889-1968), Untitled (Opus 161), 1966. Digital still image of an analog time-based Lumia work. Carol and Eugene Epstein Collection. 
dependence. Each screen poses an optical riddle and demands scrutiny and study. And yet even when the riddle is 'solved' and the virtual image is mapped onto the material screen, the visual pleasure does not abate. For the kaleidoscopic regime of images harbours no standstill where contemplation can wholly master the conflation of sculpture and image. The industrialization and standardization of the vertical screen is, no doubt, epoch-making. But the towering verticality of Screen No. 5 is of no greater consequence than the squareness of Screens Nos. 4 and 7 or the diamond-like reflections of Screen No. 6. As Eisenstein understood generations ago, the ultimate aim cannot be to replace or even augment the axiom of horizontal narrative with the axiom of vertical portraiture-be it of celluloid or iPhones, humans or ghosts, spirits or gods. No Chrétien cross to augment a squarish centre with wide and 'tall' screens. No iPhones to switch between portrait and landscape. Rather than an agenda, McElheny's Screens For Looking at Abstraction advance a recognition: there is no image without its material screen and no screen without its virtual image and no cinema without the confluence of the two.

\section{Works Cited}

Belton, John. Widescreen Cinema. Cambridge, MA: Harvard University Press, 1992. Cooke, Lynne. 'Gary Hill: “Who am I but a figure of speech?”' Parkett no. 34 (1992): 16-27.

Dean, Tacita. 'FILM.' In Film: Tacita Dean, edited by Nicholas Cullinan, The Unilever Series. London: Tate Publishing, 2011.

Deleuze, Gilles. Foucault. Translated by Seán Hand. Minneapolis: University of Minnesota Press, 1988.

Eisenstein, Sergei. 'The Dynamic Square.' In Selected Works, vol. 1: Writings 1922-1934, edited by Michael R. Taylor. London: BFI, 1991.

Elcott, Noam M. 'Darkened Rooms: A Genealogy of Avant-Garde Filmstrips from Man Ray to the London Film-Makers' Co-op and Back Again.' Grey Room 30 (2008): 6-37.

——. 'The Phantasmagoric Dispositif: An Assembly of Bodies and Images in Real Time and Space.' Grey Room 62 (2016): 42-71.

Glove and Boots. 'Vertical Video Syndrome.' YouTube, 5 June 2012. https://youtu. be/BtgzSfinwFA. Accessed on 12 November 2018.

Howell, A.S. and J.A. Dubray. 'Some Practical Aspects of and Recommendations on Wide Film Standards.'Journal of the Society of Motion Picture Engineers XIV, no. 1 (1930): 59-84.

Joseph, Branden W. The Roh and the Cooked. Berlin: August Verlag, 2012. 
Kos, Paul and Glenn Phillips. 'Paul Kos.' In California Video: Artists and Histories, edited by Glenn Phillips, pp. 142-145. Los Angeles: Getty Research Institute, 2008. Krauss, Rosalind. 'Paul Sharits.' Film Culture no. 65-66 (1978): 103-108.

Le Grice, Malcolm and P. Adams Sitney. 'Narrative Illusion vs. Structural Realism.' In Experimental Cinema in the Digital Age, edited by Malcolm LeGrice, pp. 134-152. London: BFI, 2001.

Man Ray. 'Tous les films que j'ai réalisés...' Études cinématographiques no. 38-39 (1965): 43-46.

Manjoo, Farhad. 'Vertical Video on the Small Screen? Not a Crime.' The New York Times, 12 August 2015.

McCall, Anthony. 'Line Describing a Cone and Related Films.' October no. 103 (2003): 42-62.

McEhleny, Josiah. 'Josiah McEhleny in Conversation with Daniel F. Herrmann and Tamara Trodd.' In Josiah McElheny: The Past was a Mirage I'd Left Far Behind, edited by Daniel F. Herrmann, pp. 75-85. London: Whitechapel Gallery, 2012.

Moholy-Nagy, László. Malerei Fotografie Film. Edited by Hans M. Wingler. Berlin: Gebr. Mann Verlag, 1927; reprinted 1986.

Molderings, Herbert. 'Lichtjahre eines Lebens: Das Fotogramm in der Ästhetik Laszlo Moholy-Nagys.' In Laszlo Moholy-Nagy: Fotogramme 1922-1943, edited by Renate Heyne, Floris M. Neusüss, and Herbert Molderings, pp. 8-17. München: Schirmer-Mosel, 1995 .

Roeder, Oliver. 'A Nerd's Guide To The 2,229 Paintings At MoMA.' FiveThirtyEight (blog). 28 August, 2015. http://www.fivethirtyeight.com/features/a-nerds-guideto-the-2229-paintings-at-moma. Accessed on 12 November 2018.

Schapiro, Meyer. 'On Some Problems in the Semiotics of Visual Art: Field and Vehicle in Image-Signs.' Simiolus 6, no. 1 (1972-1973): 9-19.

Schmidt, Gunnar. Weiche Displays: Projektionen auf Rauch, Wolken und Nebel. Berlin: Verlag Klaus Wagenbach, 2011.

Stein, Donna. Thomas Wilfred: Lumia. Washington, DC: Corcoran Gallery of Art, 1971.

Sterne, Jonathan. 'Space within Space: Artificial Reverb and the Detachable Echo.' Grey Room 6o (2015): 110-131.

Steyerl, Hito. The Wretched of the Screen. E-flux. Berlin: Sternberg Press, 2012.

Suger, the Abbot of St. Denis. Abbot Suger on the Abbey Church of St.-Denis and its Art Treasures. Translated by Erwin Panofsky. Second edition. Princeton: Princeton University Press, 1979.

Trott, Michael. 'Aspect Ratios in Art: What Is Better Than Being Golden?' Wolfram (blog). 18 November, 2015. http://blog.wolfram.com/2015/11/18/aspect-ratios-in-artwhat-is-better-than-being-golden-being-plastic-rooted-or-just-rational-investigating-aspect-ratios-of-old-vs-modern-paintings/. Accessed on 12 November 2018. 
Uroskie, Andrew V. Between the Black Box and the White Cube: Expanded Cinema and Postwar Art. Chicago: University of Chicago Press, 2014.

Wasserman, Norman. 'Special Projection Process Give Fantasia New Look.' International Projectionist (March 1956): 14-15.

Wilfred, Thomas. 'Light and the Artist.' In Total Theatre, edited by E.T. Kirby, pp. 252-264. New York: E.P. Dutton \& Co., 1969.

\section{About the Author}

Noam M. Elcott is associate professor of Modern and Contemporary Art and Media at Columbia University. His research focuses on Europe and North America, with an emphasis on interwar art, photography, and film. Elcott is the author of Artificial Darkness: A History of Modern Art and Media (2016). He is currently at work on Art in the First Screen Age: László Moholy-Nagy and the Cinefication of the Arts, which traverses interwar painting, architecture, photography, film, theatre, and exhibition design in the age of cinema. Elcott is an editor of the journal Grey Room, which covers architecture, art, media, and politics. His articles have appeared in leading journals like October and Aperture. 
